\title{
Sense of efficacy among beginning teachers in Sarawak
}

\begin{abstract}
This study examined the level of teachers' sense of efficacy among beginning teachers in Sarawak, Malaysia. It also sought to investigate whether there is any difference in beginning teachers' sense of efficacy in relation to gender, race and types of teacher preparation program. The study was conducted by using the teacher sense of efficacy scale. The sample consisted of 328 beginning teachers. The mean score of beginning teachers' sense of efficacy was 6.57 and the standard variation was .80 . There were significant differences in teachers' sense of efficacy in relation to race $(\mathrm{F}=3.46, \mathrm{p}<.05)$ and types of teacher preparation program $(\mathrm{F}=3.92, \mathrm{p}<.05)$. The differences in overall teacher sense of efficacy were also significant in relation to the interaction between gender and types of teacher education $(\mathrm{F}=$ $4.59, \mathrm{p}<.05)$ and interaction between all the three demographic variables $(\mathrm{F}=3.32, \mathrm{p}<.05)$. The implications of the study on the theory and practice of teachers' sense of efficacy was discussed.
\end{abstract}

